\title{
STUDI JENIS DAN KELIMPAHAN PLANKTON PADA BERBAGAI KEDALAMAN DAN HUBUNGANNYA DENGAN KOMPOSISI MAKANAN TIRAM MABE (Pteria penguin)
}

\author{
Andi Parenrengi*), Syarifuddin Tonnek*), dan Sri Ismawati*)
}

\begin{abstract}
ABSTRAK
Penelitian ini dilaksanakan di perairan Teluk Labuange Kabupaten Barru, dengan tujuan untuk mengetahui jenis dan kelimpahan plankton serta pemanfaatannya oleh tiram mabe (Pteria penguin). Identifikasi jenis dan kelimpahan plankton dilakukan pada kedalaman 2, 4 , 6, 8, dan $10 \mathrm{~m}$ (Desember 1995) dan 2, 6, dan $10 \mathrm{~m}$ (Maret 1996) berdasarkan kedalaman penempatan tiram mabe. Pengambilan contoh air dan tiram mabe dilakukan selama 24 jam yang dilaksanakan dalam dua periode pengamatan yaitu bulan Desember 1995 dan Maret 1996.

Fitoplankton yang didapatkan di perairan Teluk Labuange terdiri atas lima kelas yaitu Bacillariophyceae, Cyanophyceae, Chromonadea, Sarcodina, dan Ciliata. Kelas Bacillario. phyceae (diatom) mendominasi perairan pada setiap kedalaman, sedangkan zooplankton yang didapatkan hanya terdiri atas satu kelas yaitu krustase. Persentase kelimpahan tertinggi adalah Bacillariophyceae 98,61\% (4.044 ind./L) kemudian Cyanophyceae 0,80\% (33 ind./L), Chromonadea dan Ciliata masing-masing 0,27\% (11 ind./L) dan terendah Sarcodina 0,05\% (2 ind./L). Kisaran nilai indeks keseragaman berkisar 0,4984-0,6899 (Desember 1995) dan 0,30940.3173 (Maret 1996). Analisis lambung tiram mabe menunjukkan adanya fitoplankton Chaetoceros spp., Nitzschia spp., Thalassiotrix spp., Bacteriastrum spp., Coscinodiscus spp., Amphora spp., Rhizosolenia spp, Pleurosigma spp, Asterionella spp, Oscillatoria spp. dan Tintinopsis spp. Diatom mendominasi isi lambung tiram mabe, di mana jenis plankton yang terdapat dalam lambung tiram mabe sangat tergantung dari komposisi jenis plankton dalam perairan.
\end{abstract}

ABSTRACT: Study of plankton abundance at different water depth and related to plankton consumed by wing pearl oyster (P. penguin). By: Andi Parenrengi, Syarifuddin Tonnek and Sri Ismawati

The experiment was conducted at Labuange Bay,Barru District, South Sulawesi, and aimed to identify type and abundance of plankton and its utilization as natural food by wing oyster $(\boldsymbol{P}$. penguin). Sampling of plankton and wing oyster were carried out twice, namely in December 1995 and March 1996, at different water depths, i.e: 2, 4, 6, 8, and $10 \mathrm{~m}$ respectively.

Five classes of phytoplankton commonly found in Labuange Bay were Bacillariophyceae, Cyanophyceae, Chromonadea, Sarcodina, and Ciliata, while only one class of zooplankton Crustacea was found. Among of them, diatom was found to be dominant. The highest abundance of phytoplankton was found at $2 \mathrm{~m}$ water depth and the lowest at $10 \mathrm{~m}$ water depth. Phytoplankton abundance in percentage were Bacillariophyceae $98.61 \%(4,041$ ind. $/ \mathrm{L})$, Cyanophyceae $0.80 \%$ (33 ind. /L), Chromonadea 0.27\% (11 ind./L), Ciliata 0,27\% (11 ind./L), and Sarcodina $0.05 \%$ ( 2 ind. $/ L$ ). The plankton diversity index at Labuange Bay, ranged between 0.4984-0.6899 in Desember 1995 and between 0.3094-0.3173 in March 1996. Analysis of stomach content indicated that Bacillariophyceae (Chaetoceros spp., Nitzschia spp., Thalassiotrix spp., Bacteriastrum spp., Coscinodiscus spp., Amphora spp., Rhizosolenia spp., Pleurosigma spp., and Asterionella spp.), Cyanophyceae (Oscillatoria spp.), and Ciliata (Tintinopsis spp.) were the main plankton comsumed by wing pearl oyster. The abundance of plankton in the waters strongly correlated to its content in the stomach of wing oyster.

KEYWORDS : plankton, water depth, food composition, stomach analysis, wing oyster.

\section{PENDAHULUAN}

Tiram mabe, Pteria penguin (wing oyster) merupakan salah satu jenis bivalva penghasil mutiara dari famili Pteridae yang mempunyai prospek yang baik untuk dikembangkan. Di samping itu, beberapa jenis tiram telah dikenal sebagai penghasil mutiara yang bernilai ekonomis tinggi antara lain Pinctada maxima, P. margaritifera dan P. fucuta (Gervis \& Sims, 1992). Tiram

\footnotetext{
Peneliti pada Balai Penelitian Perikanan Pantai, Maros
} 
mutiara telah dikembangkan di Indonesia seperti di perairan Maluku Tengah dan Utara, Sulawesi Tengah dan Tenggara, Nusa Tenggara, serta Irian Jaya. Budidaya tiram mabe telah dilakukan sejak tahun 1936 di Buton, Sulawesi Tenggara (Abdullah, 1992) di mana budidaya tiram mabe di Perairan Pasarwajo Sulawesi Tenggara dilakukan pada kedalaman $6.8 \mathrm{~m}$. Benih tiram di perairan tersebut masih didapatkan sampai dengan kedalaman $10 \mathrm{~m}$, tetapi pada umummya kelimpahan semakin banyak dengan bertambahnya kedalaman sampai 3-5 m. Atmomarsono et al. (1993) mendapatkan pertumbuhan Pinctada margaritifera paling baik pada kedalaman pemeliharaan $6 \mathrm{~m}$. Sementara itu pengembangan usaha tiram mabe dimungkinkan karena melihat potensi benih dan budidaya yang cukup besar, tersebar terutama di Perairan Sulawesi Tenggara (Abdullah, 1992; Askabul, 1992; Bau, 1992; Yosman \& Pananrang, 1992) dan Perairan Maluku (Mosse et al., 1994).

Jorgensen (1966 dalam Kastoro, 1992) mela. porkan bahwa pada umumnya jenis-jenis kerang Pelecypoda tergolong pemangsa suspensi di mana sumber makanannya terdiri atas fitoplankton, bakteri, jamur, dan zat organik terlarut. Tiram mabe termasuk organisme pemakan bahan-bahan tersuspensi di dalam air (suspension feeder) dengan cara menyaring makanannya (filter feeder mechanism) sehingga kesuburan perairan, termasuk komposisi jenis dan kelimpahan plank. ton merupakan salah satu faktor utama yang perlu diperhatikan, karena akan berpengaruh terhadap ketersediaan makanan bagi tiram yang dibudidayakan. Kecerahan merupakan faktor penting yang mengindikasikan ketersediaan plankton dan bahan tersuspensi lainnya. Kecerahan dapat mempengaruhi tingkat intensitas cahaya dalam suatu perairan di mana intensitas cahaya merupakan salah satu faktor pembatas melimpahnya fitoplankton, sehingga perbedaan intensitas cahaya pada setiap kedalaman perairan akan memberikan efek perbedaan komposisi jenis, kelimpahan dan distribusi plankton dalam perairan tersebut.

Penelitian bertujuan untuk mendapatkan data dan informasi mengenai jenis, kelimpahan dan distribusi plankton, serta komposisi makanan dan frekuensi kejadian jenis plankton yang terdapat dalam isi lambung tiram mabe yang dipelihara pada berbagai kedalaman perairan. Data dan informasi ini diharapkan dapat menunjang upaya pengembangan budidaya dan pembenihan tiram mabe.

\section{BAHAN DAN METODE}

Penelitian dilaksanakan di perairan Teluk Labuange, Kabupaten Barru. Tiram mabe yang digunakan berasal dari perairan Sulawesi Tenggara yang sebelumnya diaklimatisasi selama seminggu di tempat penelitian. Tiram mabe berukuran $8.10 \mathrm{~cm}$ dimasukkan ke dalam keranjang gantung kemudian ditempatkan pada kedalaman perairan yang diinginkan yakni $2,4,6,8$, dan 10 m (Desember 1995) dan 2, 6 dan 10 m (Maret 1996). Setiap keranjang diisi tiram mabe sebanyak delapan individu yang dipelihara selama satu minggu sebelum sampling.

Pengambilan contoh plankton dan tiram mabe dilaksanakan dalam dua periode waktu yang berbeda yaitu bulan Desember 1995 dan Maret 1996. Pengambilan contoh tiram mabe (satu individu) dan plankton pada semua kedalaman pemeliharaan dilaksanakan setiap tiga jam selama 24 jam pengamatan. Contoh plankton diawetkan dengan formalin $5 \%$, sedangkan contoh tiram mabe diawetkan dengan formalin $10 \%$ untuk analisis jenis, kelimpahan, distribusi plankton, dan analisis isi lambung, serta frekuensi kejadian makanan tiram mabe. Frekuensi kejadian dihitung berdasarkan frekuensi munculnya spesies fitoplankton dalam lambung mabe yang disajikan dalam persentase. Identifikasi genera plankton berdasarkan buku kunci Sachlan (1972), Prescott (1973), Mizumo (1978), dan Yamaji (1976). Contoh plankton dianalisis di laborotorium dengan menggunakan Sedgwick Rafter Counter (SRC) dan untuk menentukan kelimpahan plankton didasarkan pada rumus APHA (1985):

$$
\text { Ind. } / \mathrm{L}=\frac{\mathrm{T}}{\mathrm{L}} \times \frac{\mathrm{P}}{\mathrm{P}} \times \frac{\mathrm{V}}{\mathrm{V}} \times \frac{1}{\mathrm{w}}
$$

di mana;

$\mathrm{T}=$ luas gelas penutup (SRC)

$\mathrm{L}=$ luas satu lapang pandang

$\mathrm{P}=$ jumlah individu plankton

$\mathrm{p}=$ jumlah lapang pandang yang diamati

$\mathrm{V}=$ volume konsentrat sampel yang disaring

$\mathbf{v}=$ volume contoh yang diamati

$\mathrm{w}=$ volume air yang disaring

Indeks keseragaman digunakan untuk menentukan dominansi satu atau beberapa spesies/ genera dalam perairan. Nilai indeks keseragaman berkisar antara 0 sampai 1 , di mana semakin besar nilainya maka jumlah individu yang didapatkan semakin seragam. Indeks keseragaman plankton 
dihitung dengan menggunakan rumus Indeks Diversitas Shannon (Ludwig \& Reynolds, 1988):

$$
\begin{aligned}
& H=-\sum\left(\frac{n i}{N}\right) \ln \left(\frac{n i}{N}\right) \\
& H \max =-\ln s \\
& E=\frac{H}{H \max }
\end{aligned}
$$

di mana:

$\mathrm{H}^{\prime}=$ indeks diversitas

$\mathrm{E}=$ indeks keseragaman

$\mathrm{ni}=$ jumlah individu setiap spesies atau genus

$\mathrm{N}=$ jumlah individu seluruh spesies atau genus

$\mathrm{s}=$ jumlah seluruh spesies atau genus

Analisis isi lambung tiram mabe dilakukan pada 64 individu (hasil sampling bulan Desember 1995 dan Maret 1996 pada berbagai kedalaman) untuk menentukan komposisi makanan dan frekuensi kejadiannya menurut petunjuk Effendie (1979). Hasil identifikasi komposisi jenis, kelimpahan, distribusi, dan frekuensi kejadian makanan tiram mabe disajikan secara deskriptif dalam bentuk tabulasi dan histogram.

\section{HASIL DAN PEMBAHASAN}

\section{Identifikasi Jenis dan Kelimpahan Plankton}

Fitoplankton yang didapatkan di perairan Teluk Labuange pada pengamatan Desember 1995 dan Maret 1996 terdiri atas lima kelas yakni Bacillariophyceae, Chromonadea, Ciliata, Sarcodina, dan Cyanophyceae. Kelas Bacillariophyceae diwakili oleh spesies Chaetoceros spp., Bacteriastrum spp., Thalassiotrix spp., Nitzschia spp., Coscinodiscus spp., Amphora spp., Biddulphia spp., Asterionella spp., dan Rhizosolenia spp. Kelas Chromonadea diwakili jenis Ceratium spp. dan Peridinium spp. sedangkan kelas Sarcodina, kelas Ciliata, dan kelas Cyanophyceae masing-masing hanya didapatkan satu spesies yaitu berturutturut Globigerina spp., Tintinopsis spp., dan Oscillatoria spp. Zooplankton terdiri atas kelas Crustacea jenis Acartia spp., Calanus spp., dan Cyclops spp. (Lampiran 1).

Di antara lima kelas fitoplankton yang teridentifikasi didapatkan bahwa Bacillariophyceae merupakan kelas yang mendominasi perairan pada semua kedalaman. Persentase kelimpahan tertinggi adalah Bacillariophyceae $98,61 \%$ (4.044
ind./L) kemudian Cyanophyceae 0,80\% (33 ind./ L), Chromonadea dan Ciliata masing-masing $0,27 \%$ (11 ind./L) dan terendah Sarcodina $0,05 \%$ (2 ind./L). Amin et al. (1993) juga melaporkan bahwa kelas Bacillariophyceae merupakan salah satu kelas yang mendominasi perairan pantai, sungai, dan tambak di Sulawesi Selatan. Chaetoceros spp. dan Nitzschia spp. mewakili kelas Bacillariophyceae yang kelimpahannya relatif besar pada lokasi budidaya $P$. margaritifera di Pasarwajo, Kapupaten Buton (Tonnek et al., 1993).

Genera Chaetoceros, Bacteriastrum, Thalassiotrix, dan Nitzschia merupakan kelompok diatom yang mendominasi perairan pada semua kedalaman dan waktu pengamatan tetapi kelimpahannya menurun dengan semakin bertambahnya kedalaman. Dominasi tersebut dimungkinkan karena keempat genera tersebut bersifat kosmopolit (Sachlan, 1972) yang hidup sebagai plankton pada permukaan sampai dasar perairan yang masih dapat disinari, bahkan dapat bersifat bentos dan perifiton. Ceratium dan Peridinium merupakan kelompok dinoflagellata yang keberadaannya kurang menguntungkan bagi organisme perairan (Sachlan, 1972), bahkan dalam k़eadaan blooming dapat membahayakan organisme akuatik. Namun hasil pengamatan di perairan Teluk Labuange, genus tersebut kelimpahannya relatif rendah yakni 5-6 ind./L. Zooplankton yang didapatkan tidak menunjukkan adanya spesies tertentu yang mendominasi perairan.

Secara umum genera yang didapatkan di perairan Teluk Labuange lebih banyak dibandingkan di perairan tempat pemeliharaan tiram mutiara di Pasarwajo (Atmomarsono et al., 1993) yang hanya terdiri atas tujuh genera yaitu Chaetoceros, Nitzschia, Pleurosigma, Surirella, Anabaena, Asterococcus, dan Nodularia.

Distribusi fitoplankton dan zooplankton secara vertikal dari kedalaman 2 sampai $10 \mathrm{~m}$ menunjukkan bahwa kelimpahan plankton semakin besar dengan semakin kurangnya kedalaman, tetapi jenis-jenis plankton yang didapatkan relatif sama pada berbagai kedalaman (Lampiran 2 dan 3). Persentase kelimpahan fitoplankton cenderung menurun dengan semakin bertambahnya kedalaman perairan, demikian juga kelimpahan zooplankton, kecuali pada bulan Maret, kelimpahan zooplankton semakin tinggi dengan bertambahnya kedalaman perairan. Persentase fitoplankton tertinggi didapatkan pada kedalaman $2 \mathrm{~m}$ $(98,85 \%)$ dan terendah pada kedalaman $10 \mathrm{~m}$ 


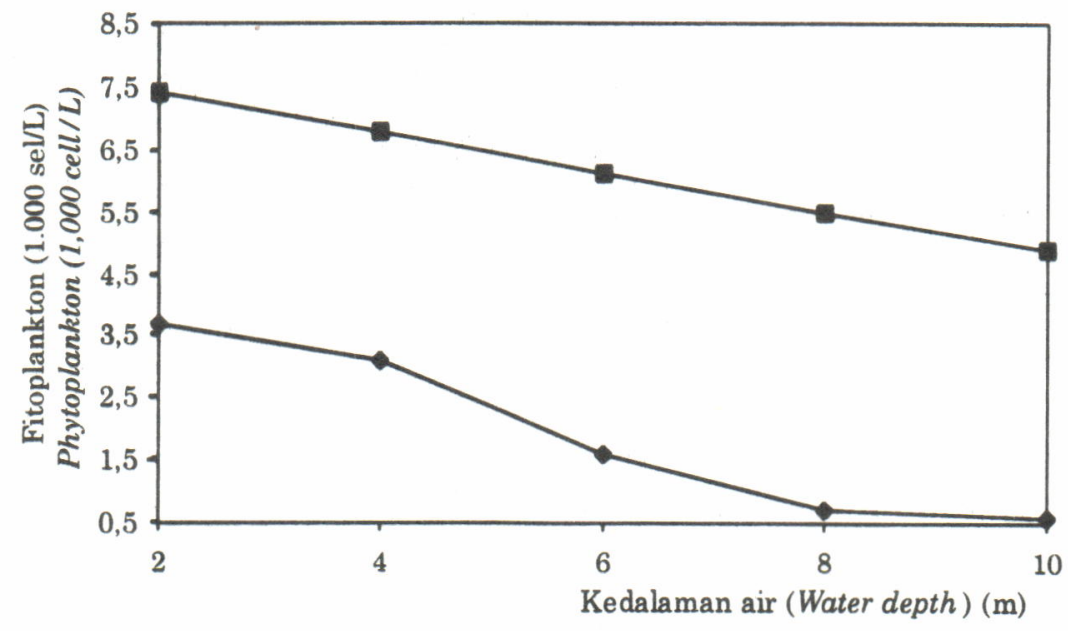

$\multimap$ December, $1995 \multimap-$ March, 1998

Gambar 1. Kelimpahan fitoplankton pada berbagai kedalaman di Teluk Labuange, Barru.

Figure 1. Phytoplankton abundance at various water depths in Labuange Bay, Barru.

(95,13\%), sedangkan sebaliknya persentase zooplankton pada bulan Maret tertinggi pada kedalam.

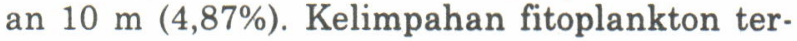
tinggi didapatkan pada kedalaman $2 \mathrm{~m}$, di mana kelimpahan tersebut semakin berkurang sampai dengan kedalaman $10 \mathrm{~m}$ (Gambar 1).

Pada periode pengamatan Desember 1995 didapatkan bahwa kelimpahan plankton pada kedalaman $2 \mathrm{~m}$ dapat mencapai 3.939 ind./L, kemudian pada kedalaman $4 \mathrm{~m}$ : 3.202 ind./L, 6 $\mathrm{m}: 1.715$ ind./L, $8 \mathrm{~m}: 767$ ind./L, dan terendah pada kedalaman $10 \mathrm{~m}$ yaitu 568 ind./L (Lampiran 2). Pola kelimpahan yang sama juga didapatkan pada pengamatan Maret 1996 yakni kelimpahan plankton tertinggi pada kedalaman $2 \mathrm{~m}$ yaitu $7.430 \mathrm{ind} . /$ $\mathrm{L}$, kemudian $6 \mathrm{~m}$ yaitu $6.288 \mathrm{ind} . / \mathrm{L}$, dan terendah pada kedalaman $10 \mathrm{~m}$ yaitu 5.028 ind./L (Lampiran 3).

Menurunnya kelimpahan fitoplankton dengan bertambahnya kedalaman perairan disebabkan karena intensitas cahaya matahari semakin berkurang dengan bertambahnya kedalaman, karena adanya fenomena absorpsi, pemantulan dan penyebaran cahaya oleh massa air. Pertumbuhan dan perkembangbiakan fitoplankton sangat dipengaruhi oleh intensitas cahaya, di mana ada kecenderungan semakin besar intensitas cahaya sampai batas tertentu, proses fotosintesis akan berlangsung dengan baik.

Distribusi plankton berdasarkan waktu pengamatan tidak menunjukkan variasi yang men- colok baik pengamatan pada bulan Desember 1995 maupun Maret 1996. Hal ini menunjukkan bahwa perbedaan kelimpahan plankton antara siang dengan malam hari relatif kecil, dibandingkan dengan perbedaan kelimpahan plankton antar berbagai kedalaman (Lampiran 4).

\section{Indeks Keseragaman}

Indeks keseragaman plankton pada berbagai kedalaman bervariasi antara 0,4984-0,6899 pada pengamatan pertama (Desember 1995) dan 0,3094-0,3173 pada pengamatan ke dua (Maret 1996), di mana nilai tersebut bervariasi di antara beberapa kedalaman. Pada kedalaman 2 m untuk rataan bulan Desember 1995 dan Maret 1996 didapatkan indeks keseragaman 0,4048 sedangkan pada kedalaman $10 \mathrm{~m}$ yaitu 0,5036 (Tabel 1 ).

Indeks keseragaman semakin besar dengan bertambahnya kedalaman. Ini menunjukkan bahwa semakin dalam perairan, perbedaan jumlah individu antara spesies relatif kurang, sedangkan pada kedalaman $2 \mathrm{~m}$ dari permukaan perairan beberapa spesies didapatkan mendominasi terutama dari kelas Bacillariophyceae yaitu Chaetoceros spp. (3.226 ind./L), Bacteriastrum spp. (312 ind./L) dan Thalassiotrix spp. (277 ind./L) (Lampiran 1). Kelimpahan Chaetoceros tersebut lebih tinggi bila dibandingkan dengan Chaetoceros yang didapatkan di perairan Teluk Piru, Seram yaitu $2.234 \mathrm{sel} / \mathrm{L}$ (Yusuf \& Praseno, 1978 dalam Wouthuyzen, 1994). 
Tabel 1. Indeks keseragaman plankton pada berbagai kedalaman di Teluk Labuange, Barru.

Table 1. Diversity index of plankton at various water depths in Labuange Bay, Barru.

\begin{tabular}{|c|c|c|c|c|c|c|}
\hline \multirow{2}{*}{$\begin{array}{c}\text { Waktu pengamatan } \\
\text { Observation time }\end{array}$} & \multicolumn{6}{|c|}{ Kedalaman air (Water depth) (m) } \\
\hline & 2 & 4 & 6 & 8 & 10 & $\begin{array}{c}\text { Rata-rata } \\
\text { Average }\end{array}$ \\
\hline \multicolumn{7}{|c|}{ Desember 1995 (December 1995) } \\
\hline $02.00 \mathrm{am}$ & 0.5330 & 0.5592 & 0.5813 & 0.6342 & 0.4932 & 0.5602 \\
\hline $05.00 \mathrm{am}$ & 0.5247 & 0.4922 & 0.4558 & 0.7535 & 0.6389 & 0.5724 \\
\hline $08.00 \mathrm{am}$ & 0.3017 & 0.2596 & 0.5142 & 0.5825 & 0.6357 & 0.4594 \\
\hline $11.00 \mathrm{am}$ & 0.5680 & 0.6140 & 0.6119 & 0.7641 & 0.7889 & 0.6694 \\
\hline $14.00 \mathrm{pm}$ & 0.4368 & 0.5486 & 0.7075 & 0.6088 & 0.7233 & 0.6050 \\
\hline $17.00 \mathrm{pm}$ & 0.3912 & 0.3879 & 0.3873 & 0.5547 & 0.7244 & 0.4747 \\
\hline $20.00 \mathrm{pm}$ & 0.5939 & 0.5148 & 0.6182 & 0.7772 & 0.8215 & 0.6651 \\
\hline $23.00 \mathrm{pm}$ & 0.6524 & 0.6109 & 0.6127 & 0.7786 & 0.6938 & 0.5602 \\
\hline Rata-rata (Average) & 0.5002 & 0.4984 & 0.5611 & 0.6817 & 0.6899 & \\
\hline \multicolumn{7}{|c|}{ Maret 1996 (March 1996) } \\
\hline $02.00 \mathrm{am}$ & 0.2421 & - & 0.2857 & - & 0.2813 & 0.3277 \\
\hline $05.00 \mathrm{am}$ & 0.2897 & - & 0.2687 & - & 0.4560 & 0.3277 \\
\hline $08.00 \mathrm{am}$ & 0.2897 & - & 0.3329 & - & 0.3485 & 0.3247 \\
\hline $11.00 \mathrm{am}$ & 0.2329 & - & 0.3199 & - & 0.2603 & 0.4377 \\
\hline $14.00 \mathrm{pm}$ & 0.2606 & - & 0.2435 & - & 0.2048 & 0.2363 \\
\hline $17.00 \mathrm{pm}$ & 0.2934 & - & 0.2182 & - & 0.2926 & 0.2681 \\
\hline $20.00 \mathrm{pm}$ & 0.4941 & - & 0.4306 & $\cdot$ & 0.2926 & 0.4058 \\
\hline $23.00 \mathrm{pm}$ & 0.4038 & - & 0.3199 & - & 0.4025 & 0.3754 \\
\hline Rata-rata (Average) & 0.3094 & - & 0.3025 & - & 0.3173 & \\
\hline
\end{tabular}

: tidak diamati (no observation)

Dominasi diatom seperti Chaetoceros juga didapatkan di perairan Maluku Tengah (Wouthuyzen, 1994) serta Chaetoceros dan Rhizosolenia di perairan Teluk Baguala, Ambon (Setiadi et al., 1991 dalam Wouthuyzen, 1994).

\section{Analisis Isi Lambung Tiram Mabe (Pteria penguin)}

Hasil analisis isi lambung tiram mabe pada pengamatan Desember 1995 dan Maret 1996 didapatkan beberapa spesies yaitu Chaetoceros spp., Bacteriastrum spp., Thalassiotrix spp., Nitzschia spp., Coscinodiscus spp., Amphora spp., Asterionella spp., Rhizosolenia spp., dan Oscillatoria spp., di mana jenis plankton yang terbanyak didapatkan adalah Chaetoceros spp., Thalassiotrix spp., Bacteriastrum spp., dan Nitzschia spp. (Lampiran 5). Spesies plankton yang didapatkan dalam lambung tiram mabe juga didapatkan di perairan penempatan tiram mabe. Hal tersebut menunjukkan bahwa tiram (bivalve) bersifat penyaring semua bahan tersuspensi dalam perairan termasuk fitoplankton (Mansour \& Gobal, 1980 dalam Gervis \& Sims, 1992).

Analisis isi lambung 64 individu tiram mabe selama bulan Desember 1995 dan Maret 1996 didapatkan bahwa frekuensi kejadian makanan tertinggi (100\%) adalah Chaetoceros spp., Nitzschia spp., Thalassiotrix spp., Bacteriastrum spp., dan Coscinodiscus spp., kemudian berturut-turut Amphora spp. dan Oscillatoria spp. $(32,8 \%)$, Rhizosolenia spp. (12,5\%), Pleurosigma spp. (10,9\%), Asterionella spp. (6,3\%), dan terendah jenis Tintinopsis spp. (3,1\%) (Gambar 2). Hasil analisis isi lambung tiram, Saccostrea cucullata juga didapatkan spesies fitoplankton seperti Rhizosolenia, Thalassiotrix, Asterionella, 


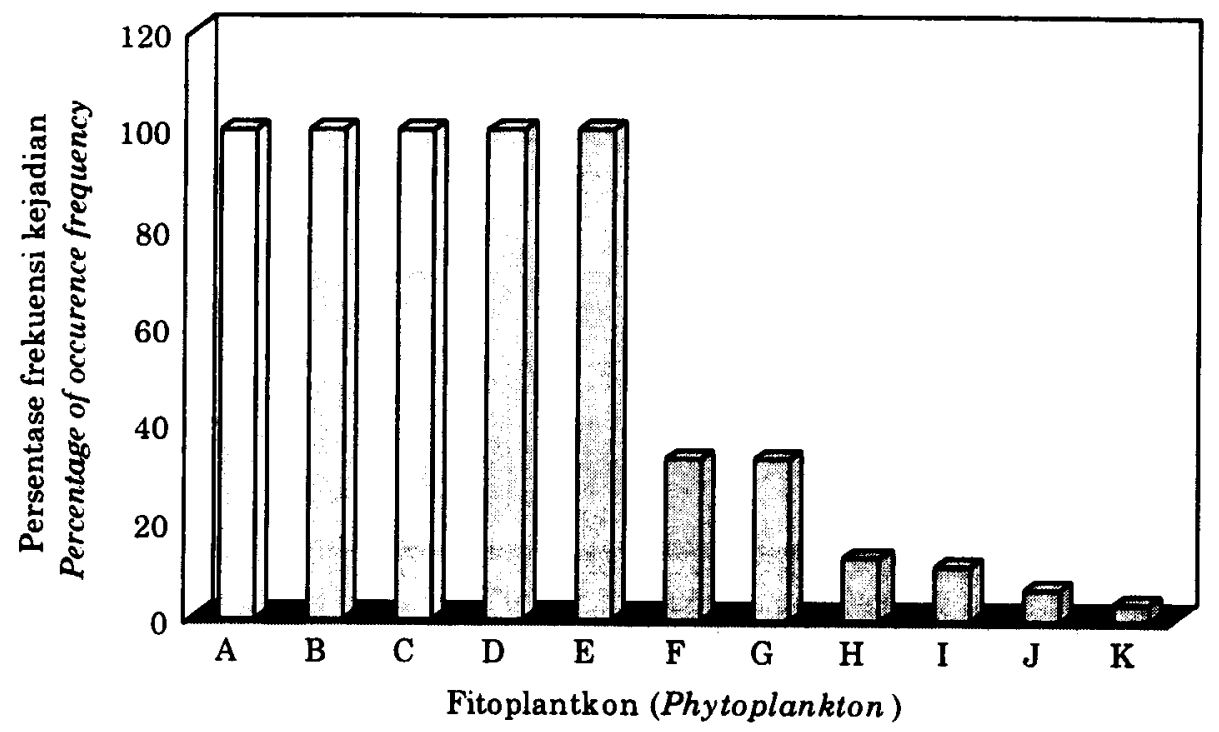

Gambar 2. Komposisi isi lambung tiram mabe, $P$. penguin dalam persentase frekuensi kejadian ( $\mathrm{A}=$ Chaetoceros spp., $\mathrm{B}=$ Nitzschia spp., $\mathrm{C}=$ Thalassiotrix spp., $\mathrm{D}=$ Bacteriastrum spp., $\mathrm{E}=$ Coscinodiscus spp., $\mathrm{F}=$ Amphora spp., $\mathrm{G}=$ Oscillatoria spp., $\mathrm{H}=$ Rhizosolenia spp., $\mathrm{I}=$ Pleurosigma spp.,J=Asterionella spp., dan $\mathrm{K}=$ Tintinopsis spp.).

Figure 2. Composition of stomachs content of wing oyster, $P$. penguin in the percentage of occurrence frequency ( $A=$ Chaetoceros spp., $B=$ Nitzschia spp., $C=$ Thalassiotrix spp., $D=$ Bacteriastrum spp., $E=$ Coscinodiscus spp., $F=$ Amphora spp., $G=$ Oscillatoria spp., $H=$ Rhizosolenia spp., I=Pleurosigma spp., $J=$ Asterionella spp., dan $K=$ Tintinopsis spp.).

Coscinodiscus, Nitzschia, Gyrosigma, Cocconeis, Bacteriastrum, dan Cerithium (Wouthuyzen, 1994).

Gambar 2 memperlihatkan bahwa diatom merupakan kelas yang banyak terdapat dalam isi lambung tiram mabe, yang kemungkinan disebab. kan berlimpahnya diatom pada perairan tersebut. Hal tersebut dapat menjadi pertimbangan dalam pengembangan budidaya dan produksi larva tiram mutiara. Sejalan dengan itu, beberapa jenis diatom telah dikembangkan sebagai pakan alami larva tiram mutiara seperti Chaetoceros spp., Skeletonema spp. dan Nitzschia sp. serta beberapa spesies dari kelas yang lain seperti Pavlova lutheri, Isochrysis spp., Chlorella spp., Nannochloropsis spp., Phaeodactylum spp. dan Tetraselmis spp. (Alagarswami et al., 1989; Gerwis \& Sims, 1992; Uchimura et al., 1989).

Hasil pengamatan terhadap analisis antara isi lambung tiram mabe pada berbagai kedalaman sampai dengan $10 \mathrm{~m}$ serta antara siang dan malam hari tidak memperlihatkan variasi yang besar (Lampiran 5). Hal ini menunjukkan bahwa tiram melakukan penyaringan setiap saat, seperti yang dilaporkan oleh Imai (1977 dalam Wouthuyzen,
1994) bahwa pada umumnya aktivitas makan oleh tiram berlangsung sepanjang hari.

\section{Kualitas Air}

Secara umum fluktuasi beberapa peubah kualitas air yang ditera selama penelitian relatif kecil, di mana kisaran beberapa peubah kualitas air seperti suhu, salinitas dan $\mathrm{pH}$ adalah berturutturut 28,6-30,0 $0^{\circ} \mathrm{C}, 32-35 \mathrm{ppt}$, dan 7,78-8,05 (Tabel 2). Kisaran tersebut masih dalam batas toleransi tiram mutiara, di mana tiram mutiara ( $P$. maxima, $P$. margaritifera dan $P$. fucuta) didapatkan hidup pada perairan dengan suhu berkisar $19-32^{\circ} \mathrm{C}$ dengan kisaran salinitas $27,2-33,7$ ppt (Gervis \& Sims 1992). Winanto et al. (1991) menyatakan bahwa tiram mutiara tumbuh baik pada suhu 27 . $29^{\circ} \mathrm{C}$, dapat mentolerir salinitas $24-50 \mathrm{ppt}$ dalam waktu 2-3 hari, tetapi salinitas optimalnya adalah 32-35 ppt. Kisaran pH yang baik untuk tiram mutiara adalah 7,8-8,6 (Mulyanto, 1995).

Kecerahan air saat pengamatan berkisar antara 4-6 m, sementara kecerahan air yang baik untuk tiram mutiara adalah 4,5-6,5 $\mathrm{m}$ (Winanto et al., 1991). Kecepatan arus permukaan saat pengamatan adalah $0.30 \mathrm{~cm} / \mathrm{dtk}$, di mana nilai 
Tabel 2. Rentang beberapa peubah kualitas air di perairan Teluk Labuange, Barru, Sulawesi Selatan.

Table 2. Ranges of water quality parameters during the experiment in Labuange Bay of Barru, South Sulawesi.

\begin{tabular}{lrc}
\hline \multicolumn{1}{c}{ Variabel (Variables) } & & Rentang (Range) \\
\hline Suhu (Temperature) & ${ }^{\circ} \mathrm{C}$ & $28.6-30.0$ \\
Oksigen terlarut (Dissolved oxygen) & $\mathrm{mg} / \mathrm{L}$ & $8.4-10.3$ \\
Salinitas (Salinity) & $\mathrm{ppt}$ & $32-35$ \\
Kecerahan (Transparency) & $\mathrm{mg} / \mathrm{L}$ & $4-6$ \\
Velositas (Current velocity) & $\mathrm{cm} / \mathrm{s}$ & $0-30$ \\
$\mathrm{pH}$ & & $7.78-8.05$ \\
$\mathrm{NO}_{2}-\mathrm{N}$ & $\mathrm{mg} / \mathrm{L}$ & $\mathrm{nd}-0.0039$ \\
$\mathrm{NO}_{3}-\mathrm{N}$ & $\mathrm{mg} / \mathrm{L}$ & $\mathrm{nd}$ \\
$\mathrm{PO}_{4}-\mathrm{P}$ & $\mathrm{mg} / \mathrm{L}$ & $0.0157-0.0520$ \\
\hline
\end{tabular}

tersebut lebih besar dari kecepatan arus yang disarankan oleh Winanto et al. (1991) untuk budidaya tiram mutiara yaitu $15-25 \mathrm{~cm} / \mathrm{dtk}$. Kisaran $\mathrm{NO}_{2}-\mathrm{N}, \mathrm{NO}_{3}-\mathrm{N}$, dan $\mathrm{PO}_{4}-\mathrm{P}$ pada berbagai kedalaman perairan tidak menunjukkan perbedaan. Rata-rata kandungan $\mathrm{NO}_{2}-\mathrm{N}$ paling tinggi adalah $0,0039 \mathrm{mg} / \mathrm{L}$ dan $\mathrm{PO}_{4}-\mathrm{P} 0,0157$. $0,0520 \mathrm{mg} / \mathrm{L}$. Nitrat dan fosfat merupakan unsur hara makro, di mana nitrogen dimanfaatkan oleh fitoplankton dalam bentuk $\mathrm{NO}_{3}-\mathrm{N}, \mathrm{NO}_{2}-\mathrm{N}$, dan $\mathrm{NH}_{4}-\mathrm{N}$ (Smayda, 1983).

\section{KESIMPULAN}

Fitoplankton yang didapatkan di perairan Teluk Labuange terdiri atas lima kelas, di mana kelas Bacillariophyceae (diatom) mendominasi perairan pada setiap kedalaman, tetapi kelimpahannya semakin menurun dengan bertambahnya kedalaman, sedangkan zooplankton yang didapatkan hanya terdiri atas satu kelas (krustase) yang diwakili tiga spesies (Acartia spp., Calanus spp., dan Cyclops spp.). Distribusi jenis plankton antar beberapa kedalaman sampai dengan $10 \mathrm{~m}$ tidak menunjukkan variasi yang besar.

Nilai indeks keseragaman cenderung meningkat dengan semakin bertambahnya kedalaman perairan. Hal tersebut menunjukkan bahwa semakin dalam perairan perbedaan kelimpahan antara spesies relatif kurang.

Diatom merupakan kelas yang memiliki frekuensi kejadian tertinggi dibandingkan kelas lainnya dalam komposisi isi lambung tiram mabe, $P$. penguin dan juga merupakan kelas yang berlimpah di perairan Teluk Labuange.

\section{UCAPAN TERIMA KASIH}

Ucapan terima kasih disampaikan kepada Rifka Pasande, Rosiana Sabang, Tamsil, dan Umar atas bantuannya dalam pelaksanaan penelitian ini.

\section{DAFTAR PUSTAKA}

Abdullah, A. 1992. Potensi sumber daya kekerangan di Kabupaten Buton. Dalam Mansur, H., Rachmansyah, A. Mustafa, dan A.M. Pirzan (eds.), Prosiding Temu Karya Ilmiah Potensi Sumberdaya Kekerangan Sulawesi Selatan dan Sulawesi Tenggara. Balai Penelitian Perikanan Budidaya Pantai, Maros. 53-60.

Alagarswami, K., S. Dharmaraj, A. Chellam, and T.S. Velayudhan. 1989. Larval and juvenile rearing of black-lip pearl oyster, Pinctada margaritifera (Linnaeus). Aquaculture 76:1-9.

Amin, M., Kusdiarti, dan S. Redjeki. 1993. Potensi plankton di perairan pantai Sulawesi Selatan untuk menunjang usaha pembenihan udang. Dalam Danakusumah, E., Rachmansyah, A.M. Pirzan, dan N.A. Rangka (eds.) Prosiding Rapat Teknis Ilmiah Penelitian Perikanan Budidaya Pantai. Balai Penelitian Perikanan Budidaya Pantai, Maros. 183-187.

APHA (American Public Health Association). 1985. Standard Methods for the Examination of Water and Wastewater. American Public Health Association, 1015 Fifteenth Street NW, Washington. 1268 pp.

Askabul. 1992. Potensi sumber daya kekerangan Kabupaten Kendari. Dalam Mansur, H., Rachmansyah, A. Mustafa, dan A.M. Pirzan (eds.), Prosiding Temu Karya Ilmiah Potensi Sumber Daya Kekerangan Sulawesi Selatan dan Sulawesi Tenggara 
Balai Penelitian Perikanan Budidaya Pantai, Maros. hal:45-52.

Atmomarsono, M., A. Sudradjat, dan S. Tonnek. 1993. Pertumbuhan japing-japing, Pinctada margaritifera pada kedalaman air yang berbeda di perairan Pasarwajo, Kabupaten Buton, Sulawesi Tenggara. J. Penelitian Budidaya Pantai 9(4):91-100.

Bau, F. 1992. Potensi sumber daya kekerangan Kabupaten Muna. Dalam Mansur, H., Rachmansyah, A. Mustafa, dan A.M. Pirzan (eds.), Prosiding Temu Karya Ilmiah Potensi Sumber Daya Kekerangan Sulawesi Selatan dan Sulawesi Tenggara. Balaj Penelitian Perikanan Budidaya Pantai, Maros. 61. 67.

Effendie, M.l. 1979. Metode Biologi Perikanan. Yayasan Dewi Sri, Bogor. 112 hal.

Gervis, M.H. and N.A. Sims. 1992. The Biology and Culture of Pearl Oyster (Bivalvia: Pteriidae). ICLARM Stud. Rev.21, Philippines. 249 pp.

Kastoro, W.W. 1992. Beberapa aspek biologi dan ekologi dari jenis-jenis moluska laut komersil yang diperlukan untuk menunjang usaha budidayanya. Dalam Mansur, H., Rachmansyah, A. Mustafa, dan A.M. Pirzan (eds.), Prosiding Temu Karya Ilmiah Potensi Sumber Daya Kekerangan Sulawesi Selatan dan Sulawesi Tenggara. Balai Penelitian Perikanan Budidaya Pantai, Maros. 68-79.

Ludwig. A.J. and R.J.F. Reynolds. 1988. Statistical Ecology. A Primer on Method and Computing. A Wiley-Interscience publication John Willey \& Sons, New York, Chichester. Brisbane, Toronto, Singapore. 337 pp.

Mizumo. T. 1978. Illustrations of the Freshwater plankton of Japan. Hoikusha Publishing. Osaka, Japan. $363 \mathrm{pp}$.

Mosse, J.W., B.G. Hutubessy, dan T. Sidabutar. 1994. Studi pendahuluan pertumbuhan kerang mutiara (Pteria penguin Roeding) yang dipelihara pada kondisi kolam dan alami. Perairan Maluku dan sekitarnya $8: 35-42$.
Mulyanto. 1995. Teknik Budidaya Laut Tiram Mutiara di Indonesia. Direktorat Jenderal Perikanan. Jakarta. 72 hal.

Prescott, G.W. 1973. Algae. Department of Biology, Michigan State University, Pubuque, Iowa, Ger. many. $956 \mathrm{pp}$.

Sachlan, M. 1972. Planktonologi. Correspondence Course Centre, Jakarta. 103 hal.

Smayda, T. 1983. The phytoplankton of estuaries. In Ketchum, B.H. (ed.), Estuaries and Enclosed Seas. Ecosystem of the World 26, Elsevier Sci. Publ. Com., Amsterdam-Oxford. 65-102.

Tonnek, S., A. Sudradjat, dan B. Pantjara. 1993. Budidaya japing-japing, Pinctada margaritifera di perairan Pasarwajo Kabupaten Buton Propinsi Sulawesi Selatan. Warta Balitdita 5(1):22-25.

Uchimura, Y., A. Komaru, K.T. Wada, H. Ieyama, M. Yamaki, and H. Furuta. 1989. Detection of induced triploidy at different ages for larvae of the Japanese pearl oyster, Pinctada fucuta martensii by microfluorometry with DAPI Staining. Aquaculture 76:1-9.

Winanto, T., S. Pontjoprawiro, dan S.B. Dhoe. 1991. Pemilihan lokasi budidaya tiram mutiara. Bulletin Budidaya Laut 3: 44-51.

Wouthuyzen, S. 1994. Analysis on the condition factor of the wild tropical oyster, Saccostrea cucullata in the Central Maluku Islands. Perairan Maluku dan Sekitarnya 8:1-13.

Yamaji, I. 1976. Illustrations of the Marine Plankton of Japan. Hoikusha Publishing, Osaka, Japan. 369 pp.

Yosman, M. dan A.A. Pananrang. 1992. Prospek dan potensi sumber daya kekerangan dalam pengembangannya di Sulawesi Tenggara. Dalam Mansur, H., Rachmansyah, A. Mustafa, dan A.M. Pirzan (eds.), Prosiding Temu Karya Ilmiah Potensi Sumber Daya Kekerangan Sulawesi Selatan dan Sulawesi Tenggara. Balai Penelitian Perikanan Budidaya Pantai, Maros. 34-44. 
Lampiran 1. Jenis dan kelimpahan plankton (ind./L) di Teluk Labuange, Barru. Appendix 1. Abundance of plankton species (ind./L) in Labuange Bay, Barru.

\begin{tabular}{|c|c|c|c|c|}
\hline \multirow{2}{*}{$\begin{array}{l}\text { Kelas } \\
\text { Class }\end{array}$} & \multirow{2}{*}{$\begin{array}{l}\text { Spesies } \\
\text { Species }\end{array}$} & \multicolumn{2}{|c|}{$\begin{array}{c}\text { Pengamatan } \\
\text { Observation }\end{array}$} & \multirow{2}{*}{$\begin{array}{c}\text { Rata-rata } \\
\text { Average }\end{array}$} \\
\hline & & $\begin{array}{l}\text { Desember } \\
\text { December }\end{array}$ & $\begin{array}{l}\text { Maret } \\
\text { March } \\
\end{array}$ & \\
\hline \multicolumn{5}{|c|}{ PHYTOPLANKTON } \\
\hline \multirow[t]{10}{*}{ Bacillariophyceae } & Chaetoceros spp. & 1.138 & 5.313 & 3.226 \\
\hline & Bacteriastrum spp. & 314 & 310 & 312 \\
\hline & Thalassiotrix spp. & 376 & 177 & 277 \\
\hline & Nitzschia spp. & 98 & 80 & 89 \\
\hline & Coscinodiscus spp. & 26 & 68 & 47 \\
\hline & Asterionella spp. & $\cdot$ & 89 & 45 \\
\hline & Amphora spp. & 9 & 25 & 17 \\
\hline & Biddulphia spp. & 1 & 7 & 4 \\
\hline & Pleurosigma spp. & - & 3 & 2 \\
\hline & Rhizosolenia spp. & $\cdot$ & 49 & 25 \\
\hline Cyanophyceae & Oscillatoria spp. & 1 & 65 & 33 \\
\hline \multirow[t]{2}{*}{ Chromonadea } & Ceratium spp. & 5 & 6 & 6 \\
\hline & Peridinium spp. & 3 & 7 & 5 \\
\hline Sarcodina & Globigerina spp. & 1 & 3 & 2 \\
\hline \multirow[t]{2}{*}{ Ciliata } & Tintinopsis spp. & 3 & 19 & 11 \\
\hline & & Sub Total & & $4: 101$ \\
\hline \multicolumn{5}{|l|}{ ZOOPLANKTON } \\
\hline \multirow[t]{5}{*}{ Crustacea } & Acartia spp. & 51 & 27 & 39 \\
\hline & Calanus spp. & 6 & - & 3 \\
\hline & Cyclops spp. & 5 & 5 & 5 \\
\hline & & Sub Total & & 47 \\
\hline & & Total & & 4.148 \\
\hline
\end{tabular}


Lampiran 2. Jenis dan kelimpahan plankton (ind./L) pada berbagai kedalaman di Teluk Labuange, Barru (Desember 1995).

Appendix 2. Abundance of plankton species (ind./L) at different water depths in Labuange Bay, Barru (December 1995).

\begin{tabular}{|c|c|c|c|c|c|}
\hline \multirow{2}{*}{$\begin{array}{l}\text { Kelas / Spesies } \\
\text { Class / Species }\end{array}$} & \multicolumn{5}{|c|}{ Kedalaman air (Waterdepth) (m) } \\
\hline & 2 & 4 & 6 & 8 & 10 \\
\hline \multicolumn{6}{|l|}{ PHYTOPLANKTON } \\
\hline \multicolumn{6}{|l|}{ Bacillariophyceae } \\
\hline Chaetoceros spp. & 2.311 & 1.878 & 876 & 334 & 290 \\
\hline Bacteriastrum spp. & 715 & 409 & 283 & 108 & $\mathbf{5 8}$ \\
\hline Thalassiotrix spp. & 580 & 663 & 369 & 185 & 84 \\
\hline Nitzschia spp. & 180 & 133 & 91 & 48 & 53 \\
\hline Coscinodiscus spp. & 46 & 30 & 18 & 19 & 18 \\
\hline Asterionella spp. & - & - & & 20 & - \\
\hline Amphora spp. & 13 & 9 & 6 & 11 & 6 \\
\hline Biddulphia spp. & 1 & 1 & 1 & - & - \\
\hline Pleurosigma spp. & - & - & . & - & - \\
\hline Rhizosolenia spp. & $\ddots$ & - & - & - & - \\
\hline \multicolumn{6}{|l|}{ Cyanophyceae } \\
\hline Oscillatoria spp. & - & 1 & - & - & - \\
\hline \multicolumn{6}{|l|}{ Chromonadea } \\
\hline Ceratium spp. & 4 & 6 & 1 & 6 & 5 \\
\hline Peridinium spp. & 3 & 3 & - & 4 & 4 \\
\hline \multicolumn{6}{|l|}{ Sarcodina } \\
\hline Globigerina spp. & 1 & $\cdot$ & $\cdot$ & - & - \\
\hline \multicolumn{6}{|l|}{ Ciliata } \\
\hline Tintinopsis spp. & 9 & $\cdot$ & 3 & 1 & 4 \\
\hline Sub Total & 3.863 & 3.133 & 1.648 & 716 & 522 \\
\hline \multicolumn{6}{|l|}{$\begin{array}{l}\text { ZOOPLANKTON } \\
\text { Crustacea }\end{array}$} \\
\hline Acartia spp. & 65 & 59 & 51 & 40 & 41 \\
\hline Calanus spp. & 6 & 5 & 10 & 3 & 4 \\
\hline Cyclops spp. & 5 & 5 & 6 & 8 & 1 \\
\hline Sub Total & 76 & 69 & 67 & 51 & 46 \\
\hline Total & 3.939 & 3.202 & 1.715 & 767 & 568 \\
\hline
\end{tabular}


Lampiran 3. Jenis dan kelimpahan plankton (ind./L) pada berbagai kedalaman di Teluk Labuange, Barru (Maret1996).

Appendix 3. Abundance of plankton species (ind./L) at different water depths in Labuange Bay, Barru (March 1996).

\begin{tabular}{|c|c|c|c|}
\hline \multirow{2}{*}{$\begin{array}{l}\text { Kelas / Spesies } \\
\text { Class / Species }\end{array}$} & \multicolumn{3}{|c|}{$\begin{array}{l}\text { Kedalaman air } \\
\text { Water depth (m) }\end{array}$} \\
\hline & 2 & 6 & 10 \\
\hline \multicolumn{4}{|l|}{ PHYTOPLANKTON } \\
\hline \multicolumn{4}{|l|}{ Bacillariophyceae } \\
\hline Chaetoceros spp. & 6.366 & 5.246 & 4.326 \\
\hline Bacteriastrum spp. & 358 & 346 & 208 \\
\hline Thalassiotrix spp. & 175 & 201 & 154 \\
\hline Nitzschia spp. & 101 & 85 & 55 \\
\hline Coscinodiscus spp. & 86 & 73 & 44 \\
\hline Asterionella spp. & 94 & 94 & 74 \\
\hline Amphora spp. & 33 & 24 & 19 \\
\hline Biddulphia spp. & 11 & 5 & 4 \\
\hline Pleurosigma spp. & 5 & 3 & 3 \\
\hline Rhizosolenia spp. & 66 & 56 & 38 \\
\hline \multicolumn{4}{|l|}{ Cyanophyceae } \\
\hline Oscillatoria spp. & 60 & 89 & 45 \\
\hline \multicolumn{4}{|l|}{ Chromonadea } \\
\hline Ceratium spp. & 8 & 7 & - \\
\hline Peridinium spp. & 8 & 7 & 6 \\
\hline \multicolumn{4}{|l|}{ Sarcodina } \\
\hline Globigerina spp. & 9 & 1 & $\cdot$ \\
\hline \multicolumn{4}{|l|}{ Ciliata } \\
\hline Tintinopsis spp. & 26 & 18 & 10 \\
\hline Sub Total & 7.406 & 6.255 & 4.986 \\
\hline \multicolumn{4}{|l|}{$\begin{array}{l}\text { ZOOPLANKTON } \\
\text { Crustacea }\end{array}$} \\
\hline Acartia spp. & 15 & 29 & 38 \\
\hline Calanus spp. & - & - & - \\
\hline Cyclops spp. & 9 & 4 & 4 \\
\hline Sub Total & 24 & 33 & 42 \\
\hline Total & 7.430 & 6.288 & 5.028 \\
\hline
\end{tabular}


Lampiran 4. Jenis dan kelimpahan plankton (ind./L) pada berbagai kedalaman dan waktu pengamtan di Teluk Labuange, Barru.

Appendix 4. Abundance of plankton species (ind./L) at different water depths and times of observation in Labuange Bay, Barru.

\begin{tabular}{|c|c|c|c|c|c|c|}
\hline \multirow{2}{*}{$\begin{array}{c}\text { Waktu pengamatan } \\
\text { Observation time }\end{array}$} & \multicolumn{6}{|c|}{ Kedalaman air (Water depth) (m) } \\
\hline & 2 & 4 & 6 & 8 & 10 & $\begin{array}{c}\text { Rata-rata } \\
\text { Average }\end{array}$ \\
\hline \multicolumn{7}{|c|}{ Desember 1995 (December 1995) } \\
\hline $02.00 \mathrm{am}$ & 5.180 & 4.730 & 1.760 & 2.230 & 1,310 & 3,062 \\
\hline $05.00 \mathrm{am}$ & 3.850 & 3,450 & 2.530 & 480 & 380 & 2,138 \\
\hline $08.00 \mathrm{am}$ & 6,170 & 4,430 & 1,450 & 370 & 200 & 2.524 \\
\hline $11.00 \mathrm{am}$ & 2,490 & 1,780 & 1,280 & 970 & 670 & 1,438 \\
\hline $14.00 \mathrm{pm}$ & 3,750 & 2,240 & 1,230 & 530 & 760 & 1,702 \\
\hline $17.00 \mathrm{pm}$ & 3,060 & 2,460 & 1,380 & 590 & 340 & 1,618 \\
\hline $20.00 \mathrm{pm}$ & 4,010 & 4,210 & 1,560 & 340 & 320 & 2,088 \\
\hline $23.00 \mathrm{pm}$ & 3,040 & 2,360 & 2,570 & 580 & 720 & 1,854 \\
\hline Rata-rata (Average) & 3,944 & 3,208 & 1,720 & 760 & 588 & \\
\hline \multicolumn{7}{|c|}{ Maret 1996 (March 1996) } \\
\hline $02.00 \mathrm{am}$ & 7,960 & $\cdot$ & 6,020 & - & 5,290 & 6,423 \\
\hline $05.00 \mathrm{am}$ & 9.910 & $\cdot$ & 7,930 & $\cdot$ & 6,270 & 8,037 \\
\hline $08.00 \mathrm{am}$ & 7,610 & $\cdot$ & 6,020 & - & 4,280 & 4,683 \\
\hline $11.00 \mathrm{am}$ & 8.230 & $\cdot$ & 6,850 & $\cdot$ & 5,600 & 6,893 \\
\hline $14.00 \mathrm{pm}$ & 8,570 & $\cdot$ & 8,950 & $\cdot$ & 8,070 & 8,530 \\
\hline $17.00 \mathrm{pm}$ & 5.540 & $\cdot$ & 4,740 & $\cdot$ & 4,120 & 4,800 \\
\hline $20.00 \mathrm{pm}$ & 4,960 & $\cdot$ & 5,100 & - & 3,900 & 4,653 \\
\hline $23.00 \mathrm{pm}$ & 4,680 & - & 4,470 & $\dot{-}$ & 2,990 & 4,046 \\
\hline Rata-rata (Average) & 7,183 & - & 6,260 & - & 5,065 & \\
\hline
\end{tabular}


Lampiran 5. Fitoplankton yang didapatkan dalam isi lambung tiram mabe, $P$. penguin. Appendix 5. Phytoplankton obtained from stomach content of wing oyster, $\boldsymbol{P}$. penguin

\begin{tabular}{|c|c|c|c|c|c|c|c|c|c|}
\hline \multirow{2}{*}{\multicolumn{2}{|c|}{$\begin{array}{l}\text { Kedalaman air } \\
\text { Water depth }\end{array}$}} & \multicolumn{8}{|c|}{ Waktu pengamatan (Observation time) } \\
\hline & & 05:00 & 08:00 & 11:00 & 14:00 & $17: 00$ & 20:00 & 23:00 & 02:00 \\
\hline \multicolumn{10}{|c|}{ Desember 1995 (December 1995) } \\
\hline \multirow[t]{6}{*}{$2 \mathrm{~m}$} & Amphora spp. & - & - & + & + & - & - & - & - \\
\hline & Bacteriastrum spp. & + & + & + & + & + & + & + & + \\
\hline & Chaetoceros spp. & + & + & + & + & + & + & + & + \\
\hline & Coscinodiscus spp. & + & + & + & + & + & + & + & + \\
\hline & Nitzschia spp. & + & + & + & + & + & + & + & + \\
\hline & Thalassiotrix spp. & + & + & + & + & + & + & + & + \\
\hline \multirow[t]{6}{*}{$4 \mathrm{~m}$} & Amphora spp. & - & - & + & + & - & - & - & - \\
\hline & Bacteriastrum spp. & + & + & + & + & + & + & + & + \\
\hline & Chaetoceros spp. & + & + & + & + & + & + & + & + \\
\hline & Coscinodiscus spp. & + & + & + & + & + & + & + & + \\
\hline & Nitzschia spp. & + & + & + & + & + & + & + & + \\
\hline & Thalassiotrix spp. & + & + & + & + & + & + & + & + \\
\hline \multirow[t]{6}{*}{$6 \mathrm{~m}$} & Amphora spp. & - & - & - & - & - & - & - & - \\
\hline & Bacteriastrum spp. & + & + & + & + & + & + & + & + \\
\hline & Chactoceros spp. & + & + & + & + & + & + & + & + \\
\hline & Coscinodiscus spp. & + & + & + & + & + & + & + & + \\
\hline & Nitzschia spp. & + & + & + & + & + & + & + & + \\
\hline & Thalassiotrix spp. & + & + & + & + & + & + & + & + \\
\hline \multirow[t]{6}{*}{$8 \mathrm{~m}$} & Amphora spp. & - & - & $\cdot$ & - & - & - & - & - \\
\hline & Bacteriastrum spp. & + & + & + & + & + & + & + & + \\
\hline & Chaetoceros spp. & + & + & + & + & + & + & + & + \\
\hline & Coscinodiscus spp. & + & + & + & + & + & + & + & + \\
\hline & Nitzschia spp. & + & + & + & + & + & + & + & + \\
\hline & Thalassiotrix spp. & + & + & + & + & + & + & + & + \\
\hline \multirow[t]{6}{*}{$10 \mathrm{~m}$} & Amphora spp. & - & - & - & - & - & - & - & - \\
\hline & Bacteriastrum spp. & + & + & + & + & + & + & + & + \\
\hline & Chaetoceros spp. & + & + & + & + & + & + & + & + \\
\hline & Coscinodiscus spp. & + & + & + & + & + & + & + & + \\
\hline & Nitzschia spp. & + & + & + & + & + & + & + & + \\
\hline & Thalassiotrix spp. & + & + & + & + & + & + & + & + \\
\hline
\end{tabular}


Lampiran 5 lanjutan (Appendix 5 continued)

\begin{tabular}{|c|c|c|c|c|c|c|c|c|}
\hline \multirow{2}{*}{$\begin{array}{l}\text { Kedalaman air } \\
\text { Water depth }\end{array}$} & \multicolumn{8}{|c|}{ Waktu pengamatan (Observation time) } \\
\hline & 05:00 & 08:00 & 11:00 & 14:00 & $17: 00$ & 20:00 & 23:00 & 02:00 \\
\hline
\end{tabular}

Maret 1996 (March 1996)

2 m Amphora spp.

Bacteriastrum spp.

Chaetoceros spp.

Coscinodiscus spp.

Nitzschia spp.

Pleurosigma spp.

Rhizosolenia spp.

Oscillatoria spp.

Thalassiotrix spp.

$6 \mathrm{~m}$ Amphora spp.

Asterionella spp.

Bacteriastrum spp.

Chaetoceros spp.

Coscinodiscus spp.

Nitzschia spp.

Pleurosigma spp.

Rhizosolenia spp.

Oscillatoria spp.

Thalassiotrix spp.

$10 \mathrm{~m}$ Amphora spp.

Asterionella spp.

Bacteriastrum spp.

Chaetoceros spp.

Coscinodiscus spp.

Nitzschia spp.

Pleurosigma spp.

Rhizosolenia spp.

Oscillatoria spp.

Thalassiotrix spp.

\begin{tabular}{|c|c|c|c|c|c|c|c|}
\hline- & - & + & + & + & + & + & + \\
\hline+ & + & + & + & + & + & + & + \\
\hline+ & + & + & + & + & + & + & + \\
\hline+ & + & + & + & + & + & + & + \\
\hline+ & + & + & + & + & + & + & + \\
\hline+ & - & + & + & + & - & - & - \\
\hline+ & + & - & - & - & + & - & + \\
\hline- & + & + & + & + & + & + & + \\
\hline+ & + & + & + & + & + & + & + \\
\hline- & - & + & + & + & - & + & + \\
\hline - & - & - & - & + & + & - & - \\
\hline+ & + & + & + & + & + & + & + \\
\hline+ & + & + & + & + & + & + & + \\
\hline+ & + & + & + & + & + & + & + \\
\hline+ & + & + & + & + & + & + & + \\
\hline- & + & + & - & - & - & - & - \\
\hline+ & - & + & - & - & + & - & + \\
\hline - & + & + & + & + & + & + & + \\
\hline+ & + & + & + & + & + & + & + \\
\hline - & - & + & + & - & - & + & + \\
\hline- & - & - & - & - & - & - & - \\
\hline+ & + & + & + & + & + & + & + \\
\hline+ & + & + & + & + & + & + & + \\
\hline+ & + & + & + & + & + & + & + \\
\hline+ & + & + & + & + & + & + & + \\
\hline - & - & + & - & - & - & - & - \\
\hline - & - & - & - & - & - & - & - \\
\hline- & + & + & + & + & + & + & + \\
\hline+ & + & + & + & + & + & + & + \\
\hline
\end{tabular}

= ada (present)

$=$ tidak ada $(a b s \rho n t)$ 